\title{
Non-Human Gene
}

National Cancer Institute

\section{Source}

National Cancer Institute. Non-Human Gene. NCI Thesaurus. Code C20157.

Genes from any non-human organism. 